\title{
Screening of Pseudomonas fluorescens against Dry Root Rot Pathogen Macrophomina phaseolina in Black Gram
}

\author{
G. Pothiraj ${ }^{1,2 *}$, A. Kamalakkannan ${ }^{2}$, V. Amirthalingam ${ }^{3}$ and A. Balamurugan ${ }^{2}$ \\ ${ }^{1}$ Division of Plant Pathology, Indian Agricultural Research Institute, \\ New Delhi-110012, India \\ ${ }^{2}$ Department of Plant Pathology, Tamil Nadu Agricultural University, Coimabtore-641003, \\ Tamil Nadu, India \\ ${ }^{3}$ Department of Plant Pathology, G. B. Pant University of Agriculture and Technology, \\ Uttarakhand 263153, India \\ *Corresponding author
}

\section{A B S T R A C T}

Black gram is one of the important pulse crops in India. Root rot of black gram caused by Macrophomina phaseolina is widely distributed in many countries and it is a devastating pathogen right from the establishment of the crop. Screening of Psuedomonas fluorescens was done against dry root rot pathogen $M$. phaseolina in black gram. The antagonistic activity of $P$. fluorescens against $M$. phaseolina was tested by dual culture technique. In

Keywords

Black gram,

Macrophomina

phaseolina, Psuedomonas

fluorescens, Carbendazim

Article Info

Accepted:

24 August 2018

Available Online:

10 September 2018 the present study ten isolates of P. fluorescens were isolated on King's B medium from rizhosphere soil of different crops grown at the Agricultural College and Research Institute, Killikulam. The bacteria were identified as P. fluorescens Pfkkm1 - Pfkkm10. Among the ten isolates, seven isolates reduced the mycelial growth of M. phaseolina. Pfkkm7 recorded lowest mycelial growth of $10 \mathrm{~mm}$ with $88.5 \%$ reduction over control. This isolates also recorded max inhibition zone of $51 \mathrm{~mm}$. Pfkkm9 recorded mycelia growth of $43 \mathrm{~mm}$ with $50.91 \%$ reduction over control and inhibition zone of $21.33 \mathrm{~mm}$. The other isolates like Pfkkm3, Pfkkm4 and Pfkkm10 reduced the mycelial growth but not to greater extent than Pfkkm7 and Pfkkm9. The isolates Pfkkm1, Pfkkm2, Pfkkm5, Pfkkm6, did not reduced the mycelia growth of $M$. phaseolina. Carbendazim reduced the dry root rot incidence and recorded lesser disease incidence of $18 \%$. Among the two P.fluorescens isolates PFKKM7 recorded lesser disease incidence of 24\%. P. fluorescens isolated Pfkkm9 also reduced the root rot incidence and recorded $40 \%$.The inoculated control recorded the maximum disease incidence of $98 \%$.The soil application of $P$. fluorescens isolates Pfkkm7 at the rate of $10 \mathrm{~g} / \mathrm{kg}$ of soil effectively reduced the dry root of black gram $(75.5 \%)$.

\section{Introduction}

Black gram Vigna radiata (L.) constitutes the important group of grain legumes which form a major source of dietary proteins of high biological value, energy, minerals and vitamins. The root rot disease caused by the soil borne fungus Macrophomina phaseolina 
(Tassi) is a major limiting factor in the mung bean production causing considerable losses. The fungus $M$. phaseolina infects more than 500 plant species worldwide (Wyllie 1993) and causes charcoal rot disease in several agronomically important crops including soybean, maize, sorghum and cotton. Root rot of black gram caused by $M$. phaselolina is of considerable importance causing a loss up to 2.2-15.7\%.

Management effective fungicide has been the most common practice till date. The alarming rate of environmental hazards both to flora and fauna, the increasing knowledge of too the effects on human health and an inclination towards sustainable agriculture has led to a more eco-friendly approach commonly known as.

Among the PGPR, fluorescent pseudomonads are the most preferred bacteria for biological control of soil-borne and foliar plant pathogens. On the above background an attempt was made to manage the root rot pathogen $M$. phseolina using $P$. fluorescence (Saravanakumar et al., 2007).

\section{Materials and Methods}

\section{Isolation of Macrophomona phaseolina from infected black gram plants}

Stem bark tissues of black gram bearing fungal sclerotia and characteristics root rot symptoms were collected for isolation of the pathogen. The tissues were cut into small pieces of $5-10 \mathrm{~mm}$ length and $2-3 \mathrm{~mm}$ thickness, surface sterilized with $1 \%$ mercuric chloride for 2 minutes and then rinsed thrice in sterile distilled water.

These pieces were placed on PDA Medium. The Petri dishes containing infected tissue were incubated in dark at $26 \pm 2^{\circ} \mathrm{C}$ for 6 days. (Meyer et al., 1973)
Isolation of Pseudomonas fluorescens from Rhizosphere soil

One gram of rhizosphere soil adhering to root surface was collected and transferred to a 250 $\mathrm{ml}$ conical flask containing $100 \mathrm{ml}$ of sterile water. After thorough shaking for 15 minutes in a shaker, different dilutions were prepared. One $\mathrm{ml}$ of each 10-5 and 10-6 dilution was pipette out and poured into the sterile petridishes. Later King's medium B (KB) (Kings et al., 1954) was poured, rotated and incubated at room temperature $\left(28 \pm 2^{\circ} \mathrm{C}\right)$ for 24 hours. After 24 hours of incubation, the bacterial growth was purified by the dilution plate technique (Wakes man and Connick, 1952). The bacterial culture was maintained in King's B broth (KB) in 30 percent (v/v) glycerol at $-80^{\circ} \mathrm{C}$.

\section{In vitro screening of Pseudomonas fluorescens against Macrophomina phaseolina}

The antagonistic activity of $P$. fluorescens against Macrophomina phaseolina was tested by dual culture technique (Dennis and Webster, 1971). Bacterial isolates were streaked at one side of Petri dish (one $\mathrm{cm}$ away from the edge) containing PDA. $9 \mathrm{~mm}$ mycelial disc from seven days old PDA culture of Macrophomina phaseolina was placed at the opposite side of petri dishes perpendicular to the bacterial streak and incubated at $28 \pm 2^{\circ} \mathrm{C}$ for 5-7 days. Petri dishes inoculated with fungal discs alone served as control.

Three replications were maintained for each isolate. Observation on width of inhibition zone and mycelia growth of test pathogen was recorded and per cent inhibition of pathogen growth was calculated by using the formula proposed by Vincent (1927).

Per cent inhibition $(\mathrm{I})=\mathrm{C}-\mathrm{T} / \mathrm{C} \times 100$; 
Where: C- mycelial growth of pathogen in control and

T- Mycelial growth of pathogen in dual plate.

Development of talc -based formulation of Plant Growth Promoting Rhizobacteria

Ten gram of carboxy methylcellulose was mixed with $1 \mathrm{~kg}$ of talc powder and the $\mathrm{pH}$ was adjusted to 7.0 by adding $15 \mathrm{~g}$ of calcium carbonate. The mixture was then autoclaved for 30 minutes for two consecutive days. The P.fluorescens strains Pfkkm 7 and Pfkkm 9 were grown in King's B medium (KMB) and nutrient broth for 48 hours, respectively. 400 $\mathrm{ml}$ of the bacterial inoculum was then added to $1 \mathrm{~kg}$ of the talc mixture and mixed well under sterile conditions. The product was dried under shade to bring the moisture content to less than 20 per cent. The formulation was packed in polythene bags, sealed and kept under room temperature (Vidhyasekaran and Muthamilan, 1995).

\section{Effect of $P$. fluorescens against dry root rot disease of black gram under pot culture experiment}

Potting medium (red soil: cow dung: manure at $1: 1: 1 \mathrm{w} / \mathrm{w} / \mathrm{w}$ ) was autoclaved for $1 \mathrm{~h}$ for two consecutive days and filled in pots. The talc-based formulations of Pfkkm 7and Pfkkm 9 were applied to the potting mixture at the rate of $10 \mathrm{~g}$ per $\mathrm{kg}$ of soil. Carbendazim (fungicide) was used as a standard treatment for comparison. The fungicide was applied as soil drenching at the recommended dosage (1g/ liter of water). The culture of Macrophomina phaseolina, mass multiplied in sand maize medium (Riker and Riker, 1936) (sand and maize powder at the ratio of 19: 1) was incorporated with potting medium at the rate of $20 \mathrm{~g}$ per $\mathrm{kg}$ of soil. The black gram variety Vamban 4 was sown at the rate of 10 seeds per pot and root rot disease incidence was recorded on 45 days after sowing and expressed as percentage.

\section{Statistical analysis}

The results of all the experiments were analyzed independently. The treatment means were compared by Duncan's Multiple Range Test-DMRT (Gomez and Gomez, 1984). The package used for analysis was IRRISTAT version 92-1 developed by the International Rice Research Institute Biometrics unit, the Philippines.

\section{Results and Discussion}

Isolation of Maorophomina phaseolina from infected from black gram plants

The black gram plants sowing typical dry root rot symptoms were collected for the isolation of pathogen. A fungus was constantly isolated from the infected root tissues and sub cultured on PDA slants. A mycelium of the fungus is ashy-grey in color, septate and branched. It produces large number of small, minute, micro sclerotia. These micro sclerotia are spherical to irregular in shape, black coloured, with mycelial attachment, based on the morphological character, the fungus was identified as Macrophomina phaseolina (Fig. $1)$.

Macrophomina Phaseolina has wide host range and infects pulses, oilseeds and millets and other medicinal plant. Saravanakumar and Samiappan (2006) isolated Macrophomina phaseoina from the dry root disease infected Groundnut plants.

\section{Isolation of Pseudomonas flurorescens from rhizosphere soil}

Pseudomonas is a potential biological control agent against several soil borne pathogens. These beneficial bacteria harbour in the 
rhizosphere soil of different crops. Pseudomonas fluorescens was successfully isolated from the rhizosphere soil on kings B medium by several authors' including Basha et al., (2014).

In the present study ten isolates of $P$. fluorescens well isolated on king's B medium from rizhosphere soil of different crops grown in the agricultural college and research Institute, killikulam. Based on the morphological and biochemical characteristics', the bacteria were identified as and named as Pseudomonas fluorescens Pfkkm 1 to 10. These bacterial isolates were sub cultured on king's B slants and stored at $5^{\circ} \mathrm{c}$ for further studies (Table 1 and Fig. 2).

\section{In vitro screening of Pseudomonas fluorescens against Macrophomina phaseolina}

Ten Pseudomonas fluorescens isolates were screened for their effectiveness in reducing the medical growth of dry root rot pathogens $M$. phaseolina by dual culture method among the ten isolates, seven isolates reduced the mycelial growth of $M$. phaseolina of each
Pfkkm7 of recorded lowest mycelial growth of $10 \mathrm{~mm}$ width $88.5 \%$ reduction over control. This isolates also recorded max inhibition zone of $51 \mathrm{~mm}$.the mycelia growth of $43 \mathrm{~mm}$ and inhibition zone of $21.33 \mathrm{~mm}$.the other isolates like Pfkkm3, Pfkkm4 and Pfkkm10 reduced the mycelial growth but no to the lesser extent on compared to Pfkkm7 and Pfkkm9.the isolates Pfkkm1, Pfkkm2, Pfkkm5, Pfkkm6,did not reduced the mycelia growth of Macrophomina phaseolina, (Table 2).

Govindappa et al., (2009) screened 38 Pseudomonas fluorescens isolate against $M$. phaseolina. Among these 13 isolates were capable of checking the mycelia growth of $M$, phaseolina.

\section{Development of talc based formation of Pseudomonas fluorescens}

Talc based formulation of Pfkkm7 and 9 are prepared by following standard procedure given by Vidhyasekaran and Muthamilan (1995) and these formulations were packed in white polythene bag and stored for further studies.

Table.1 Isolation of Pseudomonas fluorescens isolates from rhizosphere soils

\begin{tabular}{|l|l|l|}
\hline S. No & Bacterial Culture & Crop \\
\hline $\mathbf{1}$ & Pfkkm1 & Cotton \\
\hline $\mathbf{2}$ & Pfkkm2 & Green Gram \\
\hline $\mathbf{3}$ & Pfkkm3 & Seasame \\
\hline $\mathbf{4}$ & Pfkkm4 & Horse Gram \\
\hline $\mathbf{5}$ & Pfkkm5 & Cowpea \\
\hline $\mathbf{6}$ & Pfkkm6 & Thenai \\
\hline $\mathbf{7}$ & Pfkkm7 & Red Gram \\
\hline $\mathbf{8}$ & Pfkkm8 & Sorghum \\
\hline $\mathbf{9}$ & Pfkkm9 & Black Gram \\
\hline $\mathbf{1 0}$ & Pfkkm10 & Maize \\
\hline
\end{tabular}


Table.2 Effect of Pseudomonas fluorescens isolates on the mycelia growth of Macrophomina phaseolina

\begin{tabular}{|l|c|c|c|c|}
\hline S. No & $\begin{array}{c}\text { P.fluorescens isolates } \\
\text { Mycelial growth* } \\
(\mathbf{m m})\end{array}$ & $\begin{array}{c}\text { Mycelial growth* } \\
\text { reduction over control) }\end{array}$ & $\begin{array}{c}\text { Inhibition Zone* } \\
(\mathbf{m m})\end{array}$ \\
\hline $\mathbf{1}$ & Pfkkm1 & $87.3^{\mathrm{e}}$ & $0.34^{\mathrm{e}}$ & $0.47^{\mathrm{cd}}$ \\
\hline $\mathbf{2}$ & Pfkkm2 & $87.6^{\mathrm{e}}$ & $0.00^{\mathrm{e}}$ & $0.5^{\mathrm{cd}}$ \\
\hline $\mathbf{3}$ & Pfkkm3 & $62.0^{\mathrm{d}}$ & $29.20^{\mathrm{d}}$ & $3.0^{\mathrm{cd}}$ \\
\hline $\mathbf{4}$ & Pfkkm4 & $86.0^{\mathrm{e}}$ & $1.82^{\mathrm{e}}$ & $0.43^{\mathrm{cd}}$ \\
\hline $\mathbf{5}$ & Pfkkm5 & $87.6^{\mathrm{e}}$ & $0.00^{\mathrm{e}}$ & $0.37^{\mathrm{d}}$ \\
\hline $\mathbf{6}$ & Pfkkm6 & $87.6^{\mathrm{e}}$ & $0.00^{\mathrm{e}}$ & $0.5^{\mathrm{cd}}$ \\
\hline $\mathbf{8}$ & Pfkkm7 & $10.0^{\mathrm{a}}$ & $88.50^{\mathrm{a}}$ & $51.0^{\mathrm{a}}$ \\
\hline $\mathbf{9}$ & Pfkkm8 & $52.0^{\mathrm{c}}$ & $40.60^{\mathrm{c}}$ & $4.33^{\mathrm{c}}$ \\
\hline 10 & Pfkkm9 & $43.0^{\mathrm{b}}$ & $50.91^{\mathrm{b}}$ & $21.33^{\mathrm{b}}$ \\
\hline 11 & Pfkkm10 & $86.6^{\mathrm{e}}$ & $1.10^{\mathrm{e}}$ & $0.57^{\mathrm{cd}}$ \\
\hline
\end{tabular}

Table.3 Effect of talc formulation of Pseudomonas fluorescens against root rot disease under pot culture experiment

\begin{tabular}{|l|l|l|l|l|}
\hline S. No & Treatment & Dosage & $\begin{array}{l}\text { Dry root rot incidence } \\
(\%)^{*}\end{array}$ & $\begin{array}{l}\text { reduction } \\
\text { control }\end{array}$ \\
\hline 1 & P. fluorescens Pfkkm 7 & $10 \mathrm{~g} / \mathrm{kg}$ & $24.0^{\mathrm{b}}$ & $75.5^{\mathrm{b}}$ \\
\hline $\mathbf{2}$ & P. fluorescens Pfkkm 9 & $10 \mathrm{~g} / \mathrm{kg}$ & $40.0^{\mathrm{c}}$ & $59.0^{\mathrm{c}}$ \\
\hline 3 & Carbendazim & $0.1 \%$ & $18.0^{\mathrm{a}}$ & $81.6^{\mathrm{a}}$ \\
\hline 4 & Control & - & $98.0^{\mathrm{d}}$ & - \\
\hline
\end{tabular}

Mean of five replications

In a column, mean followed by a common letter (s) are not significantly different at $5 \%$ level by DMRT

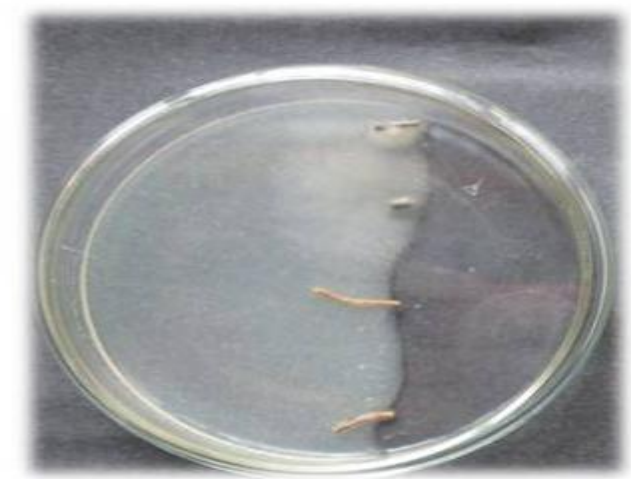

Half Plate Technique

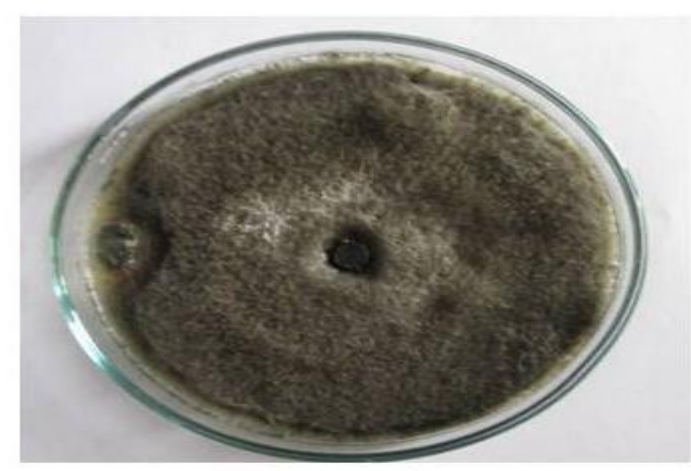

Pure cultume 


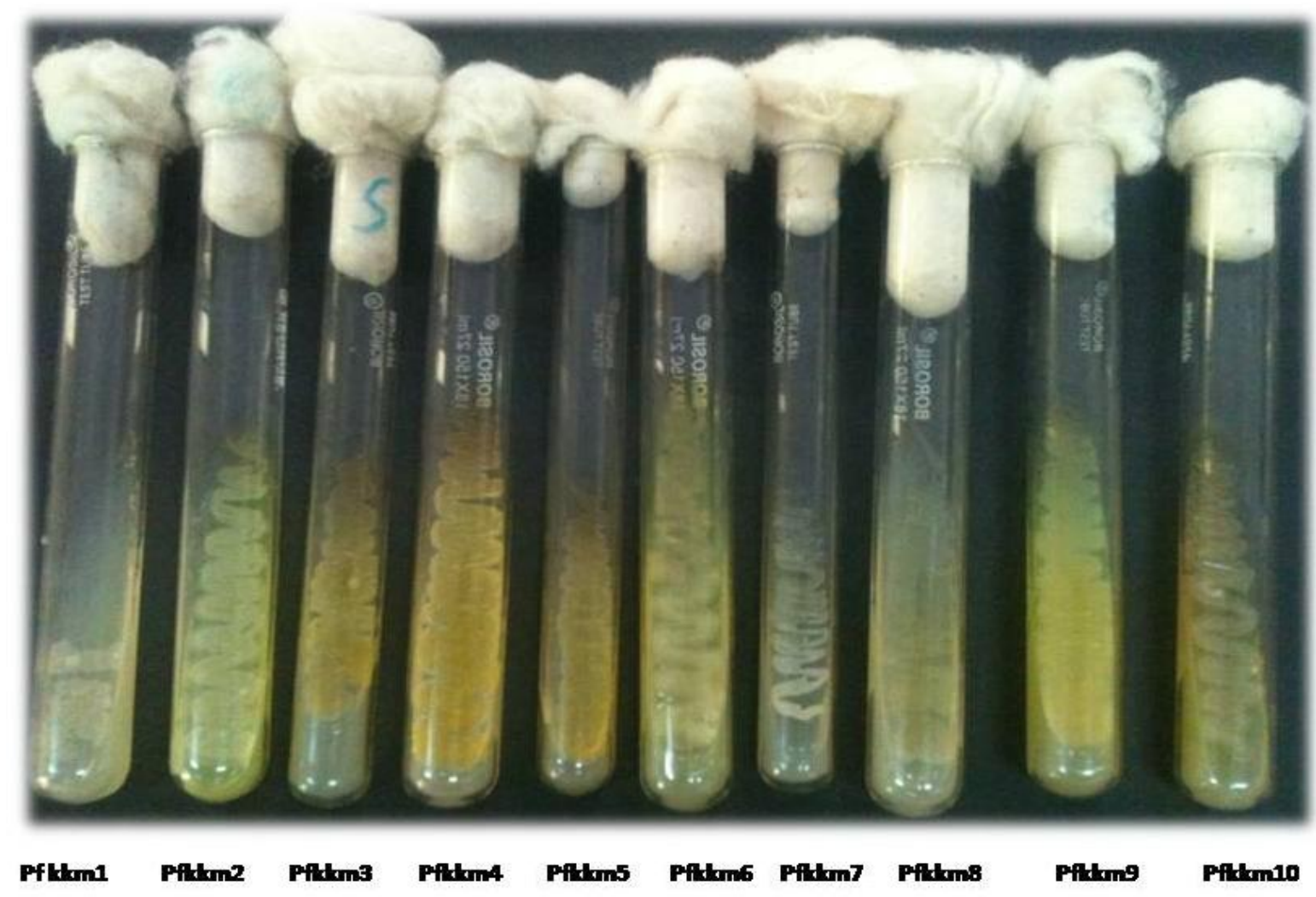

Fig 2.Culture of Psendomonos ftwonesoens on King's shats

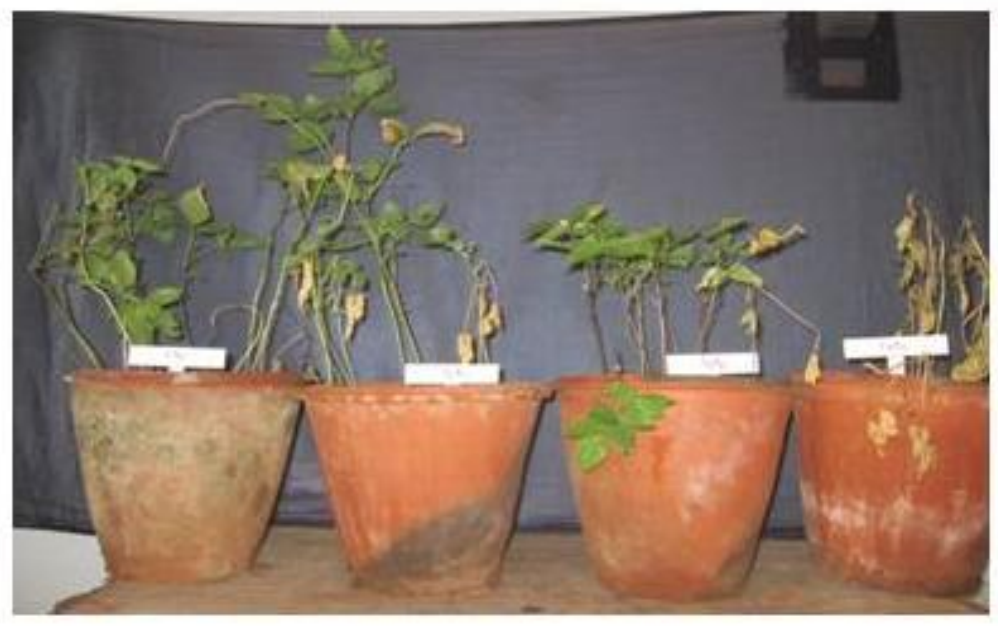

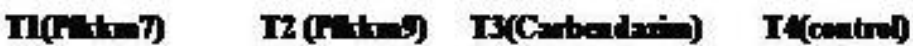

Fig 3. Effect of Psewdononas ftwonesens aginst dry reet ret under pet culture cendition 
Vidhyasekaran and Muthamilan (1995) developed talc formulation of Pseudomonas fluorescens isolates Pf1 with the population of $1.3 \times 10^{7} \mathrm{cfu} / \mathrm{g}$ on 240 days of storage.

Nandakumar et al., (2001) developed talc based formulation Pseudomonas fluorescens isolates Pf1 and Pf7.

Effect of Pseudomonas fluorescens against dry root rot disease of black gram under pot culture experiment

The talc based formulation of Pseudomonas fluorescens isolates Pfkkm7 and Pfkkm9 was evaluated against the dry root rot disease of black gram under pot culture experiment and the result are presented in Table 3. The standard chemical carbendazim was used as check. Among the three treatments the chemical check carbendazim reduced the dry root rot incidence and recorded lesser disease incidence of 18\%.among the two Pseudomonas fluorescens isolates Pfkkm7 recorded lesser disease incidence of $24 \%$.

Pseudomonas fluorescens isolated Pfkkm9 also reduced the root rot incidence and recorded $40 \%$.the inoculated control recorded the maximum disease incidence of $98 \%$.the variation in the effectiveness of two isolates might be due to difference in the antibiotic production, $\mathrm{HCN}$ production, siderophore production etc. (Fig. 3).

Nandakumar et al., (2000) screened two talc based formulation namely Pf1 and Fp7 against sheath blight pathogen Rhizoctonia solani under pot culture experiment.

Saravanakumar and Samiyappan (2006) screened talc based formulation of Pseudomonas fluorescens and formed that TDK1 were effective in reducing the dry root rot disease caused by Macrophomina phaseolina.
In the present studies also soil application of Pseudomonas fluorescens Pfkkm 7 effectively reduced the dry root rot of black gram caused by Macrophomina phaseolina.

Environmental and consumer concerns have focused interest on the development of biological control agents as an alternative, environmentally-friendly strategy for the protection of agricultural and horticultural crops against soil borne pathogens. The soil application of Pseudomonas fluorescens isolates Pfkkm7 at the rate of $10 \mathrm{~g} / \mathrm{kg}$ of soil effectively reduced the dry root of black gram $(75.5 \%)$.

\section{References}

Basha, S.A., Begum, $\mathrm{S}$ and Raghavendra. 2014. Search for Agrochemical and Heavy Metal Tolerant Strains of Pseudomonas fluorescens and Rhizobium. Indian Journal of Plant Protection. 42 (1): 71-77.

Dennis, C. and Webster, J., 1971a, Antagonistic properties of species of groups of Trichoderma I. Production of non-volatile antibiotics. Transactions of Brutish Mycological Society, 57: 25-29.

Gomez KA, Gomez AA 1984. Statistical procedure for Agricultural Research. John Wiley and Sons Limited, USA New York 680 pp.

Govindappa, M., Ravi Shankar, Rai V. and Lokesh, S. 2011 African Journal of Agricultural Research Vol. 6(29), pp. 6256-6266.

King, E.O., Ward, M.K. and Raney, D.E. 1954. Two simple media for the demonstration of pyocyanine and fluorescein. J. Lab. Chin. Med., 44: 301-307.

Meyer, W. A, J. B. Sinclair and M. N. Khare.1973. Biology of Macrophomina phaseolina in soil studies with selective media. Phytopathology. 63: 613-620. 
Nandakumar, R., Babu, S., Viswanathan, R., Sheela, J., Raguchander, T. and Samiyappan, R. 2001. A new bioformulation containing plant growth promoting rhizobacterial mixture for the management of sheath blight and enhanced grain yield in rice. Bio Control. 46(4): 493-510.

Riker AJ, Riker AS 1939. Introduction to research on plant diseases. John. Swift, C.M.C., New York. 117 p.

Saravanakumar, D., Vijayakumar, C., Kumar, N. and Samiyappan, R. 2007. PGPR induced defense responses in the tea plant against blister blight disease. Crop Protect. 26: 556-565.
Vidhyasekaran, P., and Muthamilan, M. 1995. Development of formulations of Pseudomonas fluorescens for control of chickpea wilt. Plant Dis. 79, 782-786.

Waksman, S. A. and W. J. Connick. Jr. 1952. A tentative outline of the plate method for determining the number of microorganisms in the soil. Soil Science, 14: 27-28.

Wyllie, T.D., 1993. Charcoal Rot. In: Compendium of Soybean Diseases, Sinclair, J.B. and P.A. Backman (Eds.). 3rd edn. APS Press, St. Paul, MN, pp: 30-33.

\section{How to cite this article:}

Pothiraj, G., A. Kamalakkannan, V. Amirthalingam and Balamurugan, A. 2018. Screening of Pseudomonas fluorescens against Dry Root Rot Pathogen Macrophomina phaseolina in Black Gram. Int.J.Curr.Microbiol.App.Sci. 7(09): 3300-3307.

doi: https://doi.org/10.20546/ijcmas.2018.709.409 